\title{
Congruity of the Polymorphisms in the Expressed and Noncoding Parts of the Gli-B1 Locus in Common Wheat
}

\author{
Yulia Popovych ${ }^{1}$, Sabina Chebotar ${ }^{1}$, Viktor Melnik ${ }^{2,+}{ }^{+}$, Marta Rodriguez-Quijano ${ }^{2}$, \\ Laura Pascual ${ }^{2}$, William John Rogers ${ }^{3}$ and Eugene Metakovsky ${ }^{2, *}$ \\ 1 Department of Genetics and Molecular Biology, National I.I. Mechnikov University, 65058 Odessa, Ukraine; \\ popovych1818@gmail.com (Y.P.); s.v.chebotar@onu.edu.ua (S.C.) \\ 2 Unit of Genetics, Department of Biotechnology_Plant Biology, Universidad Politécnica de Madrid, \\ 28040 Madrid, Spain; meller@vigg.ru (V.M.); marta.rurquiaga@upm.es (M.R.-Q.); \\ laura.pascual@upm.es (L.P.) \\ 3 Departamento de Biología Aplicada, CIISAS, CIC-BIOLAB, CONICET-INBIOTEC, CRESCA, \\ Facultad de Agronomía, Universidad Nacional del Centro de la Provincia Buenos Aires, Av. Rep. Italia 780, \\ 7300 Azul, Provincia de Buenos Aires, Argentina; rogers@faa.unicen.edu.ar \\ * Correspondence: emetakovsky@gmail.com \\ † Current address: Vavilov Institute of General Genetics, Russian Academy of Sciences, \\ 119991 Moscow, Russia.
}

Received: 8 August 2020; Accepted: 28 September 2020; Published: 4 October 2020

check for updates

\begin{abstract}
The previously defined pairs of primers GliB1.1 and GliB1.2 were found to produce three and four principal variants, respectively, of PCR sequence length for the $\gamma$-gliadin pseudogene in 46 Triticum aestivum L. cultivars from 15 countries carrying 19 known alleles at the Gli-B1 locus. A congruity was established between this polymorphism, allelic sets of the Gli-B1-produced gliadins (especially of the electrophoretic mobility in acid gels of the encoded $\gamma$-gliadin) and the presence in the wheat genotype of the Gli-B5b $+R g-1$ allelic combination. Six different alleles at the Gli-B1 locus encoding an identical $\gamma$-gliadin produced a PCR sequence of about 400 bp (GliB1.1). Nine Gli-B1d-carrying genotypes from four countries produced an identical sequence of about $409 \mathrm{bp}$ (GliB1.2), while three cultivars with Gli-B1h and four with Gli-B1b produced three and two specific sequences, respectively, of slightly different length. Allele Gli-B1j might be the result of recombination between coding and noncoding DNA sequences within the Gli-B1 locus. These observations imply that genetic diversity of the agriculturally important region of chromosome $1 \mathrm{~B}$ marked by variants of the Gli-B1 locus is rather limited among common wheat cultivars of the 20th century, specifically to eight principal versions. These might have been incorporated into common wheat from diverged genotypes of diploid donor(s), and, due to the scarcity of recombination, subsequently maintained relatively intact. As well as its evolutionary significance, this information is of potential use in wheat breeding and we consider it likely that novel variants of the Gli-B1 locus will be found in hitherto unstudied germplasm.
\end{abstract}

Keywords: Triticum aestivum L.; $\gamma$-gliadins; Gli-B1; polymorphism; molecular markers; PCR analysis

\section{Introduction}

The gliadins are major wheat endosperm storage proteins [1]; the characterisation of the structure of their encoding loci and of their allelic variation is an important field of study due to (i) their being an integral constituent of gluten, the composition of which is one of the principal determinants of end-use quality; (ii) the presence within some of their amino acid sequences of epitopes that are toxic 
in a proportion of the population; and (iii) most importantly for crop improvement programmes, their potential use as selective markers through linkage to other genes affecting quality or other agronomic traits. In common wheat, their synthesis is mainly controlled by six major gliadin-encoding loci (Gli-A1, Gli-B1, Gli-D1, Gli-A2, Gli-B2 and Gli-D2) located in the distal regions of the short arms of the homeologous chromosome groups 1 and $6[1,2]$. A single wheat genotype produces more than 50 different gliadin polypeptides [3] belonging to three major types, the $\alpha_{-}^{-,} \gamma_{-}^{-}$, and $\omega$-gliadins. The primary and domain structures of gliadins of different types is known $[4,5]$.

The diversity of gliadin polypeptides produced by a given genotype can be readily revealed using a simple acid gel electrophoresis procedure (APAGE). Analysis of segregating progenies from intervarietal crosses by this method showed that any allele at a Gli locus encodes two or more gliadin polypeptides (a block of electrophoretic bands) inherited together almost as a Mendelian unit, i.e., with virtually no recombination, and showing multiple allelism [6,7]. Hence, it is firmly established that any Gli locus in its different allelic states harbours different sets of expressed gliadin genes encoding various gliadin polypeptides.

The recombination rate is distributed non-proportionally along wheat chromosomes [8-10] and the distance between expressed genes in high recombination areas is considerable, reaching $55-120 \mathrm{~Kb}$ per $1 \mathrm{cM}$ of genetic distance [11]. The Glu-3 loci, mapped in the distal region of the short arms of homoeologous group 1 close to the Gli-1 loci [1,2], have been shown to locate in the high recombination region, but the average distance between expressed genes inherited together of one Glu-3 locus was as large as $81 \mathrm{~Kb}$, and, in some cases, even much larger [12]. The size of one storage protein gene, including its regulatory sequences, is about $0.8-1.5 \mathrm{~Kb}[4,13]$.

Gliadin pseudogenes and gene fragments located between expressed genes account for more than $80 \%$ of all gliadin-coding DNA sequences found at a Gli locus [14]. PCR sequence length polymorphism was discovered among some wheat species and a few common wheat cultivars for the $\gamma$-gliadin pseudogene GAG56B located within the Gli-B1 locus [15]. $\gamma$-Gliadin SNP markers (PCR primers GliB1.1 and GliB1.2) specific for a pseudogene located inside the Gli-B1 locus were also developed. Each of 50 Australian common wheat cultivars tested produced a PCR sequence with either primer GliB1.1 (369 bp) or GliB1.2 (397 bp), whereas three cultivars carrying the 1BL.1RS translocation (and therefore no DNA of the Gli-B1 locus) did not result in amplification [16].

More than 20 allelic variants of the Gli-B1 locus were revealed in about 1000 officially registered common wheat cultivars worldwide [7]. These alleles were not proportionally distributed over this germplasm; instead, significant differentiation was observed, where cultivars bred in a particular country carried only a few of the known Gli-B1 alleles. For example, more than $70 \%$ and $20 \%$ of cultivars bred in Australia during the 20th century had alleles Gli-B1b and Gli-B1i, respectively [17], meaning there is only narrow genetic variation at the Gli-B1 locus among Australian cultivars.

In this work, we aimed to verify whether the Gli-B1 alleles carried by a range of wheat cultivars would produce one of the two PCR sequences observed using two primers denominated GliB1.1 or GliB1.2 [16]. Additionally, we compared the level of genetic diversity between gliadin-encoding and noncoding parts of the Gli-B1 locus (the locus marks the agriculturally important $[8,11]$ distal region of chromosome 1B) among common wheat cultivars bred in the 20th century. For this purpose, 46 common wheat genotypes from 15 countries with different known alleles at the Gli-B1 locus were selected.

\section{Materials and Methods}

\subsection{Plant Materials}

Most of the grain samples of common wheat (T. aestivum L.) cultivars were obtained from genetic and/or breeding laboratories in their countries of origin. Some samples were taken from local collections of Spain and Ukraine. In total, 43 registered and three unregistered cultivars (wheat genotypes) from 15 countries were selected, from our list of approximately 1000 cultivars studied [7], to cover the widest possible allelic variation at the Gli-B1 locus in common wheat germplasm of the 20th century. 
Names of cultivars, country of origin, and year of registration and spring/winter habit were taken from the internet site wheatpedigree.net.

\subsection{Alleles at the Gli-B1 Locus and PCR Sequence Length Polymorphism in the Set of Cultivars Studied}

Alleles at the Gli-B1 locus were distinguished through the application of current knowledge of the gliadin polypeptide blocks encoded by each allele and observed in acid polyacrylamide gel electrophoregrams (APAGE) of gliadin proteins of single seeds [7].

DNA was extracted from dry single seeds using the CTAB method [18]. PCR amplification was performed in the thermocycler Analytik Jena (Flex Cycler, Germany) using the GliB1.1 and GliB1.2 primers [16]. Products of amplification for each cultivar were fractionated in $7 \%$ polyacrylamide gels $(280 \mathrm{~V})$ for two hours and stained as proposed by the Silver sequence TM DNA Sequencing System Technical Manual (Promega, Madison, WI, USA; https://www.promega.de/-/media/files/resources/ protocols/technical-manuals/0/silver-sequence-dna-sequencing-system-protocol.pdf). The program GelAnalyzer 19.1 was used for the calculation of the approximate length of the products of amplification by comparing them with the set of standard markers pUc19/Mspl containing fragments of known length. Each fine difference in the length of the PCR sequence was registered in neighbouring lanes of a slab gel and confirmed in different runs.

\section{Results}

\subsection{Allelic Variation at the Gli-B1 Locus and PCR Product Length Polymorphism among the Cultivars Studied}

\subsubsection{Allelic Variation}

In 46 cultivars (wheat genotypes) studied, 19 different alleles at the Gli-B1 locus (including the allele Gli-B1l represented by the 1BL.1RS translocation) were distinguished (Table 1). Gliadin protein electrophoregrams of some of the wheat genotypes studied, and blocks of gliadin electrophoretic bands controlled by each of 18 alleles (all except Gli-B1l), are shown in Figure 1 and Figure S1.

Table 1. Cultivars (grain samples) studied and their habit, country of origin, year of release, Gli-B1 allele, and the approximate length of the PCR product obtained.

\begin{tabular}{lccccccc}
\hline & $\begin{array}{c}\text { Cultivar or } \\
\text { Grain Sample }\end{array}$ & Habit & Country & Year & $\begin{array}{c}\text { Allele } \\
\text { Gli-B1 }\end{array}$ & Primer & Length $^{2}$ \\
\hline 1 & Bezostaya-1 & w & Russia & 1959 & $b$ & GliB1.1 & 369 \\
\hline 2 & Gabo & s & Australia & 1942 & $b$ & GliB1.1 & 369 \\
\hline 3 & Marquis & s & Canada & 1907 & $b$ & GliB1.1 & 369 \\
\hline 4 & Mironovskaya-808 & w & Ukraine & 1963 & $b$ & GliB1.1 & 369 \\
\hline 5 & “Kavkaz" 3 & & & & $b$ & GliB1.1 & 369 \\
\hline 6 & Federation & s & Australia & 1901 & $i$ & GliB1.1 & 400 \\
\hline 7 & Insignia & s & Australia & 1946 & $i$ & GliB1.1 & 400 \\
\hline 8 & Mentana & s & Italy & 1913 & $k$ & GliB1.1 & 400 \\
\hline 9 & Pane-247 & w & Spain & 1960 & $k$ & GliB1.1 & 400 \\
\hline 10 & Titien & w & France & 1985 & $m$ & GliB1.1 & 400 \\
\hline 11 & Aragon-03 & s, w & Spain & 1940 & $o$ & GliB1.1 & 400 \\
\hline 12 & Potam-70 & s & Mexico & 1970 & $p$ & GliB1.1 & 400 \\
\hline 13 & Gazul & s & Spain & 1992 & $r$ & GliB1.1 & 400 \\
\hline 14 & “Argelato" ${ }^{3}$ & & & $m$ & GliB1.1 & 400 \\
\hline
\end{tabular}


Table 1. Cont.

\begin{tabular}{|c|c|c|c|c|c|c|c|}
\hline & $\begin{array}{c}\text { Cultivar or } \\
\text { Grain Sample } \\
\end{array}$ & Habit & Country & Year & $\begin{array}{l}\text { Allele } \\
\text { Gli-B1 }\end{array}$ & Primer & Length $^{2}$ \\
\hline 15 & Cluj-650 & $\mathrm{w}$ & Rumania & 1954 & $j$ & GliB1.1 & 400 \\
\hline 16 & Intensivnaya & $\mathrm{i}$ & Kyrgyzstan & 1978 & $n$ & GliB1.1 & 372 \\
\hline 17 & Goelent & $\mathrm{w}$ & France & 1985 & $q$ & GliB1.1 & 372 \\
\hline 18 & Salmone & $\mathrm{w}$ & Italy & 1980 & $s$ & GliB1.1 & 372 \\
\hline 19 & Cartaya & $\mathrm{s}$ & Spain & & $l$ & GliB1.1 & - \\
\hline 20 & Chinese-Spring & $\mathrm{s}$ & China & - & $a$ & GliB1.2 & 415 \\
\hline 21 & Cajeme-71 & $\mathrm{s}$ & Mexico, USA & 1971 & $d$ & GliB1.2 & 409 \\
\hline 22 & Katepwa & $\mathrm{s}$ & Canada & 1981 & $d$ & GliB1.2 & 409 \\
\hline 23 & Laura & $\mathrm{s}$ & Canada & 1986 & $d$ & GliB1.2 & 409 \\
\hline 24 & Pavon-76 & $\mathrm{s}$ & Mexico & 1976 & $d$ & GliB1.2 & 409 \\
\hline 25 & Rinconada & $\mathrm{s}$ & Spain & 1981 & $d$ & GliB1.2 & 409 \\
\hline 26 & Roblin & $\mathrm{s}$ & Canada & 1986 & $d$ & GliB1.2 & 409 \\
\hline 27 & Suneca & $\mathrm{s}$ & Australia & 1981 & $d$ & GliB1.2 & 409 \\
\hline 28 & Yecora-S & $\mathrm{s}$ & Mexico & 1972 & $d$ & GliB1.2 & 409 \\
\hline 29 & "Inia-66" 3 & & & & $d$ & GliB1.2 & 409 \\
\hline 30 & Diego & $\mathrm{s}$ & Spain & 1983 & $c$ & GliB1.2 & 397 \\
\hline 31 & Prinqual & $\mathrm{s}$ & France & 1978 & $c$ & GliB1.2 & 397 \\
\hline 32 & Siete-Cerros-66 & $\mathrm{s}$ & Mexico & 1966 & $c$ & GliB1.2 & 397 \\
\hline 33 & Escualo & $\mathrm{w}$ & Spain & 1981 & $e$ & GliB1.2 & 397 \\
\hline 34 & Glenlea & $\mathrm{s}$ & Canada & 1972 & $e$ & GliB1.2 & 397 \\
\hline 35 & Arminda & $\mathrm{w}$ & Netherlands & 1976 & $f$ & GliB1.2 & 397 \\
\hline 36 & Cappelle-Desprez & $\mathrm{w}$ & France & 1946 & $f$ & GliB1.2 & 397 \\
\hline 37 & Darius & $\mathrm{w}$ & France & 1974 & $f$ & GliB1.2 & 397 \\
\hline 38 & Recital & $\mathrm{w}$ & France & 1986 & $f$ & GliB1.2 & 397 \\
\hline 39 & Sideral & $\mathrm{w}$ & France & 1990 & $f$ & GliB1.2 & 397 \\
\hline 40 & "Libero" 3 & & & & $f$ & GliB1.2 & 397 \\
\hline 41 & Argelato & $\mathrm{s}, \mathrm{w}$ & Italy & 1964 & $g$ & GliB1.2 & 397 \\
\hline 42 & Galahad & $\mathrm{w}$ & UK & 1983 & $g$ & GliB1.2 & 397 \\
\hline 43 & Ardec & $\mathrm{s}$ & Belgium & 1979 & $h$ & GliB1.2 & 402 \\
\hline 44 & Caia & $\mathrm{s}$ & Portugal & - & $h$ & GliB1.2 & 403 \\
\hline 45 & Krasnodonka & $\mathrm{w}$ & Ukraine & 1969 & $h$ & GliB1.2 & 401 \\
\hline 46 & Newcaster & $\mathrm{w}$ & USA & 1946 & $h$ & GliB1.2 & $403 ?^{4}$ \\
\hline
\end{tabular}

${ }^{1}$ In bold, the cultivars whose gliadin electrophoregrams are shown in the Figure 1. ${ }^{2}$ The approximate length (bp) of PCR product in cultivars with different alleles at the Gli-B1 locus. Three or more single seeds for each grain sample giving a definite PCR product were analysed and no intra-varietal non-uniformity was noted for any of the cultivars studied. ${ }^{3}$ The name was written on the label. As the genotype of this sample's seeds was different from that of the cultivar with this name studied earlier (Metakovsky et al. 2018), the allele at the Gli-B1 locus was identified in this sample using gliadin electrophoresis (data not shown). ${ }^{4}$ For the cultivar Newcaster, only a very weak PCR product was obtained; therefore, its length was not definitively established. 

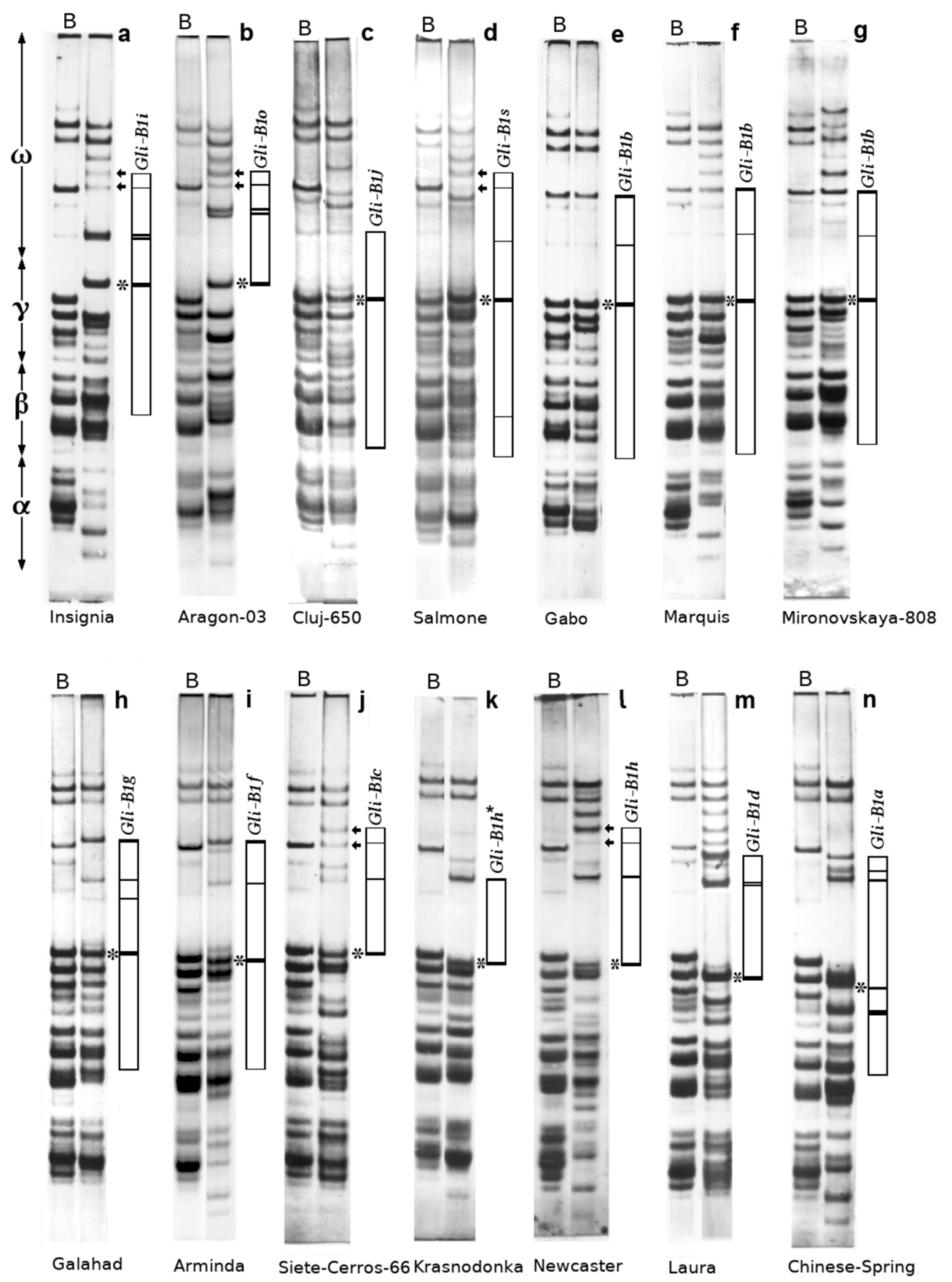

Figure 1. Gliadin electrophoregrams (APAGE) of some wheat cultivars studied. (a) Insignia; (b) Aragon-03; (c) Cluj-650; (d) Salmone; (e) Gabo; (f) Marquis; (g) Mironovskaya-808; (h) Galahad; (i) Arminda; (j) Siete-Cerros-66; (k) Krasnodonka; (1) Newcaster; (m) Laura; (n) Chinese-Spring. $\mathrm{B}$, the cultivar Bezostaya-1. Blocks of jointly inherited gliadin electrophoretic bands are shown schematically. The major $\gamma$-gliadin (asterisk) and $\omega$-gliadins encoded by the allele Gli-B5b (arrows) are indicated. *: see text.

Alleles at the Gli-B1 locus differed, in particular, in the electrophoretic mobility (EM) in APAGE of their encoded major $\gamma$-gliadin polypeptide. There were six main variants of the EM of this $\gamma$-gliadin (for example, from the slowest to the fastest, Figure 1a,d,e,k,m,n).

Two variants (I and II) of relatively slow EM for this $\gamma$-gliadin were observed in several alleles per variant. Thus, variant I (the slowest $\gamma$-gliadin) occurred in alleles Gli-B1i (Figure 1a), o (Figure 1b), 
$k, m, p$ and $r$; these alleles, with their $\gamma$-gliadin of apparently identical EM, differed among them in the composition of the encoded $\omega$-gliadins (Figure S1). Variant II occurred in alleles Gli-B1j (Figure 1c), $s$ (Figure 1d), $n$ and $q$.

Alleles of variant III encoded this $\gamma$-gliadin of intermediate EM (Figure 1e-j), although the $\gamma$-gliadin encoded by the allele Gli-B1f had a slightly higher EM compared with that of other alleles of the group (for example, Figure 1h,i; Figure S1). In contrast, alleles Gli-B1b and Gli-B1c differed considerably from each other in their encoded blocks and from those produced by other alleles of variant group III, Gli-B1e, g, and $f$ (Figure S1). Therefore, alleles Gli-B1b and Gli-B1c were considered as two more independent variants of the Gli-B1 locus.

Three variants of the major $\gamma$-gliadin of greater EM each occurred in an individual allele: Gli-B1h (Figure 1k,1), Gli-B1d (Figure 1m), and Gli-B1a (the fastest $\gamma$-gliadin, Figure 1n).

\subsubsection{PCR Product Length Polymorphism}

At least seven principal variants of the PCR product length were revealed when the 46 selected cultivars from around the world were tested in our study, three variants with the GliB1.1 primers (Figure 2, zone A) and four with the GliB1.2 set (Figure 3, zone A). The approximate length of these products varied from $369 \mathrm{bp}$ (GliB1.1) to $415 \mathrm{bp}$ (GliB1.2) (Table 1).

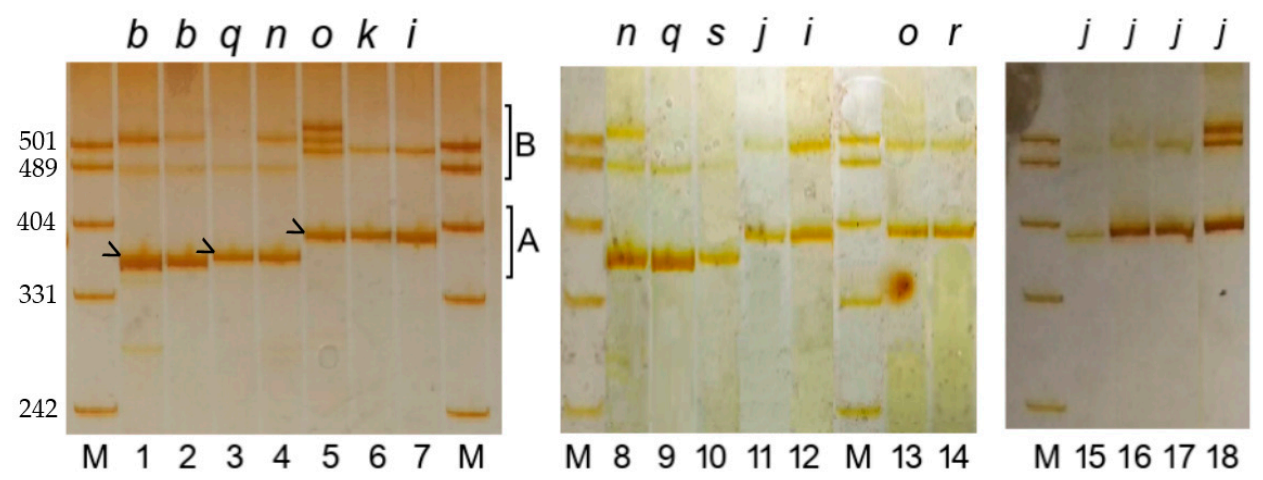

Figure 2. PCR product length polymorphism (GliB1.1 primers) among wheat cultivars. 1, Gabo; 2 , Marquis; 3, Goelent; 4, Intensivnaya; 5, Aragon-03; 6, Mentana; 7, Insignia; 8, Intensivnaya; 9, Goelent; 10, Salmone; 11, Cluj-650; 12, Federation; 13, Aragon-03; 14, Gazul; 15, 16, 17, 18, Cluj-650. Alleles at the Gli-B1 locus are indicated above lanes. M, marker pUC19/Mspl, with DNA fragment lengths in bp given on the left-side of the figure. The three principal variants are signalled by $>$ in the left-hand panel of the figure.
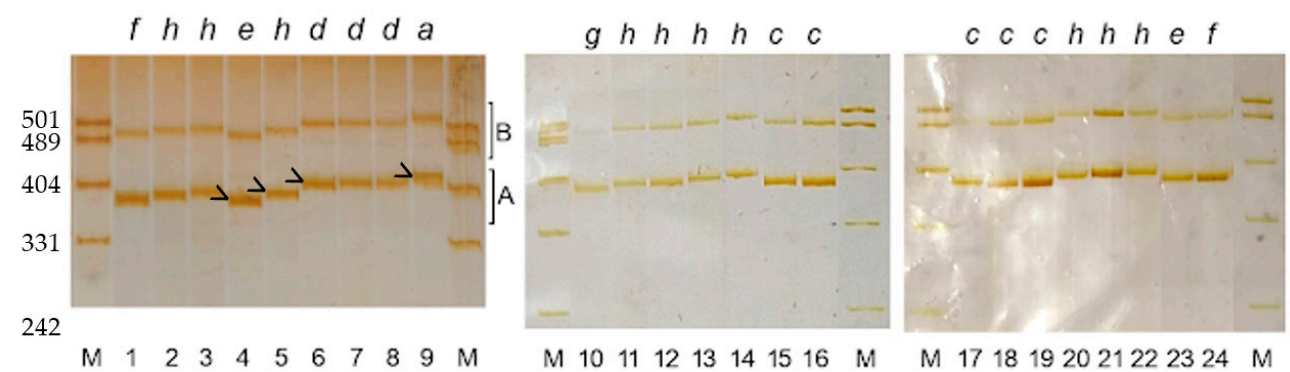

Figure 3. PCR product length polymorphism (GliB1.2 primers) among wheat cultivars. 1, Galahad; 2, Krasnodonka; 3, Caia; 4, Glenlea; 5, Ardec; 6, Laura; 7, Suneca; 8, Inia-66; 9, Chinese-Spring; 10. Argelato; 11, 12, Krasnodonka; 13, Ardec; 14, Caia; 15, Siete-Cerros-66; 16, Cappelle-Desprez; 17, Diego; 18, Prinqual; 19, Siete-Cerros-66; 20, Krasnodonka; 21, Ardec; 22, Caia; 23, Escualo; 24, Arminda. Alleles at the Gli-B1 locus are indicated above lanes. M, marker pUC19/Mspl, with DNA fragment lengths in bp given on the left-side of the figure. The four principal variants are signalled by $>$ in the left-hand panel of the figure. 


\subsection{The Correspondence between PCR Product Polymorphism and Allelic Variation at the Gli-B1 Locus}

The alleles tested in our work fell into two contrasting groups, in accordance with previous

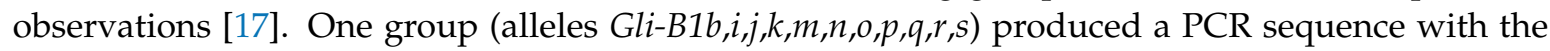
GliB1.1 primers (Figure 2), while the other (Gli-B1a,c,d,e,f,g,h) gave a product with the GliB1.2 primers (Figure 3). Generally, the alleles encoding the slow-moving $\gamma$-gliadins (groups I and II) and the allele Gli-B1b produced PCR sequences with the primers GliB1.1, whereas the other alleles did so with the GliB1.2 (Table 1). Hence, variants of the Gli-B1 locus encoding slow-moving $\gamma$-gliadins were accessible for the GliB1.1 primers and faster moving $\gamma$-gliadins were accessible for the GliB1.2 primers. As expected, the cultivar Cartaya carrying the 1BL.1RS translocation (the Gli-B1l allele) did not give a PCR product with either pair of primers (Table 1).

A strict congruency was discovered among the EM variants of the $\gamma$-gliadin and the PCR sequence length variants of a $\gamma$-gliadin pseudogene tested. For example, the lowest EM of the Gli-B1 encoded $\gamma$-gliadin of variant group I corresponded to the PCR (GliB1.1) sequence of approximately $400 \mathrm{bp}$. Alleles of group II (except Gli-B1j) generated the PCR (GliB1.1) sequence of $372 \mathrm{bp}$. Alleles Gli-B1e and Gli-B1g, differing in the presence of one minor $\omega$-gliadin, as well as the allele Gli-B1f encoding a $\gamma$-gliadin of slightly higher EM (Figure 1h,i; Figure S1), each produced the PCR (GliB1.2) sequence of $397 \mathrm{bp}$. The alleles Gli-B1d and Gli-B1a encoding different fast-moving $\gamma$-gliadins gave PCR (GliB1.2) products of $409 \mathrm{bp}$ and $415 \mathrm{bp}$, respectively (Table 1; Figure 3).

The allele Gli-B1b (Figure 1e-g) produced a unique PCR sequence, the shortest observed amongst all alleles studied, of $369 \mathrm{bp}$ (Table 1), and its controlled block differed strongly from those encoded by alleles of group III (Figure S1). Therefore, we consider the apparent equivalence of the EM of the encoded $\gamma$-gliadins of the group III and the Gli-B1b as being coincidental.

The allele Gli-B1c, while differing significantly from the other alleles of group III in its block's composition (the major $\omega$-gliadin was absent and the major $\gamma$-gliadin was weaker) (compare Figure $1 \mathrm{~h}-\mathrm{j}$ ), gave a PCR (GliB1.2) sequence identical in length to that of the other alleles of the group (Table 1).

\subsection{The Probable Recombinational Nature of the Allele Gli-B1j}

The allele Gli-B1j occurred in only one cultivar, Cluj-650, in more than 1000 common wheat cultivars studied to date (Table S1 in [7]). The EM of the $\gamma$-gliadin encoded by this allele was similar to those controlled by the group II alleles, for example, Gli-B1s (Figure 1c,d, respectively). Nevertheless, the PCR sequence produced by this cultivar was of approximately $400 \mathrm{bp}$ in length, which is characteristic of the group I alleles encoding the slowest $\gamma$-gliadin (Figure 2, lanes 8-14; Table 1).

We suggest that the allele Gli-B1j might be the product of a rare intralocus recombination event. As a result, the Gli-B1 locus could have generated this allele by obtaining its $\gamma$-gliadin coding DNA (tested with protein electrophoresis) from some allele belonging to group II (any of Gli-B1s, $q$ or $n$ ) and its noncoding DNA (tested with the use of the GliB1.1 primers) from some allele of group I. The alternative mutational transition of the EM of the $\gamma$-gliadin from group I into the other known group II polypeptides seems much less probable. In addition, the composition (set of gliadin polypeptides) of the Gli-B1j encoded block was similar to that encoded by the group II alleles, not to those of group I (Figure S1).

\subsection{Variation in PCR Product Length among Cultivars Having Identical Alleles at the Gli-B1 Locus}

As a rule, the same allele occurring in different wheat genotypes produced a PCR sequence of the same apparent length. For example, nine genotypes with the allele Gli-B1d produced PCR sequences (GliB1.2) of approximately 409 bp (Table 1; Figure 3, lanes 6, 7, 8).

However, some genotypes with identical alleles at Gli-B1 might provide PCR sequences differing slightly in length, with the allele Gli-B1h being the most interesting of this kind of observation. The Gli-B1h encoded $\gamma$-gliadin has its own unique EM in different cultivars (data not shown), but this allele produced, among three cultivars studied, three PCR (GliB1.2) sequences of slightly different 
length (approximately, 400-403 bp) that were not, however, produced by any other allelic variant of the locus. The shortest sequence was reproducibly produced by this allele in cultivar Krasnodonka and the longest in cultivar Caia, with the length of the PCR product of the cultivar Ardec probably intermediate between these two variants (Figure 3, lanes 2, 3, 5; 12, 14, 13; and 20, 22, 21, respectively). Two different grain samples of Krasnodonka were used with identical results (lanes 11, 12).

A further example was given by four cultivars carrying allele Gli-B1b, where two of the cultivars, Marquis and Gabo, produced identical PCR sequences (Figure 2, lanes 1, 2), slightly shorter (Figure 4, lanes 1, 4-9) than those in the remaining two, Bezostaya and Mironovskaya-808 (Figure 4, lanes 2, 3, 10-14).

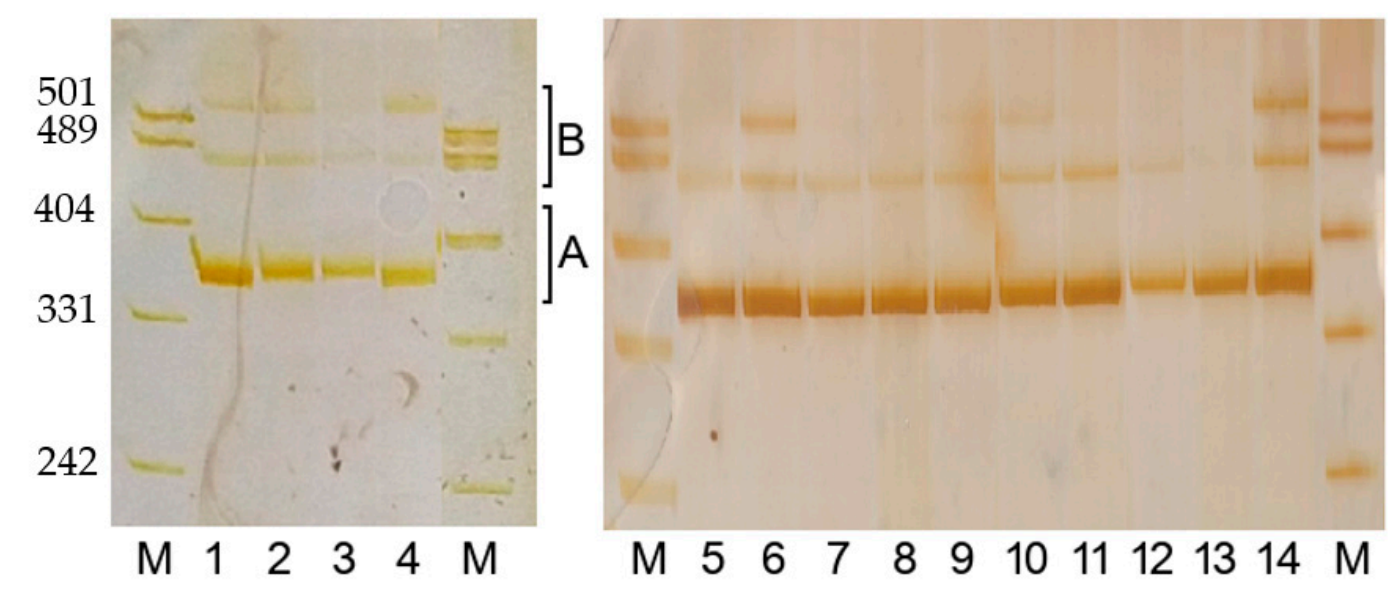

Figure 4. PCR product differences between cultivars carrying allele Gli-B1b in their genotypes 1, Gabo; 2, Bezostaya-1; 3, Mironovskaya-808; 4, Marquis; 5, 6, Gabo; 7, 8, 9, Marquis; 10, 11, Bezostaya-1; $12,13,14$, Mironovskaya-808. M, marker pUC19/Mspl, with DNA fragment lengths in bp given on the left-side of the figure.

A final example was given by the allele Gli-B1c, which, when present in the cultivar Diego (Figure 3, lane 17), might generate a longer PCR product compared with the other cultivars carrying this allele, Prinqual and Siete-Cerros-66 (Figure 3, lanes 18, 19).

The cases of a small difference of the length of the PCR product among cultivars with the same allele help to confirm the congruity between the EM of the encoded $\gamma$-gliadin and the particular length of the PCR product.

\subsection{Polymorphism of the PCR Products in "Zone B" of the Electrophoregram}

In addition to the polymorphism detected in "zone A" of the DNA electrophoregram, variation was observed among PCR-derived DNA fragments of higher length ("zone B"). As a rule, the DNA sequence in this zone was about 100 bp longer compared to zone $\mathrm{A}$ in the same genotype. For example, the approximate length of the PCR product in zone B was about $497 \mathrm{bp}$ and $495 \mathrm{bp}$ for the alleles of groups I and III, respectively. Although the nature of the PCR products in zone B remains to be studied, the polymorphism in this zone is reasonably reproducible and may contribute to the polymorphism of the noncoding sequences of the Gli-B1 locus.

For example, this polymorphism reinforced the difference between some wheat genotypes carrying different alleles at the Gli-B1 locus, but with PCR products (in zone A) of apparently identical length. The most striking difference in zone B of two DNA electrophoregrams identical in zone A was observed between cultivar Aragon-03 (Gli-B1o) and other cultivars having alleles of group I, for example, Mentana (Gli-B1k) and Insignia (Gli-B1i) (Figure 2, lanes 5, 6, 7, respectively). The less prominent, but reproducible, differences in zone B were observed between some seeds of Gabo (Figure 2, lane 1; Figure 4, lane 6) and Marquis (Figure 2, lane 2; Figure 4, lane 7); between cultivars Goelent (Figure 3, lanes 3,9) and Intensivnaya (Figure 3, lanes 4, 8); and so on. 
Furthermore, some cases were observed of differences in zone B among seeds of the same cultivar, for example, in the cultivar Cluj-650 (Figure 2, lanes 15-18), in cultivars with the allele Gli-B1b, Gabo (Figure 4, lanes 5, 6), Bezostaya-1 (lanes 10,11) and Mironovskaya-808 (lanes 12-14), but not in the cultivar Marquis (lanes 7-9).

\subsection{The PCR Sequence Corresponds to Genotype, Not to the Label of the Grain Sample under Study}

Four grain samples studied contained some seeds representing other genotypes than those identified previously in these cultivars. For example, the seeds of the grain sample labelled "Kavkaz" gave a PCR product (of length 369 bp), in spite of the fact that the Russian cultivar Kavkaz is one of the best known carriers and donors of the 1BL.1RS translocation and, therefore, lacking a true Gli-B1 locus from its genotype (Table 1). Gliadin analysis (APAGE) of seeds of this sample showed that its genotype included allele Gli-B1b (data not shown), and therefore its labelling as "Kavkaz" was incorrect.

The genotype of only one of the two grain samples of the cultivar Argelato studied included the allele Gli-B1g characteristic of this cultivar. There were two more cases of discrepancy between genotypes of grains studied earlier [7] and in this work, Inia-66 and Libero. Thus, it is remarkable that the PCR product always corresponded to genotypes identified by APAGE in this work, not to the name of the cultivar written on the label (Table 1). The presence of admixtures of alien genotypes in grain samples of wheat and errors in labelling was noted earlier in different wheat collections [19-21].

One seed of the Canadian cultivar Katepwa successfully produced PCR sequences with both pairs of primers, $409 \mathrm{bp}$ (GliB1.2) and $372 \mathrm{bp}$ (GliB1.1). We suggest that this seed was heterozygous at the Gli-B1 locus for allele Gli-B1d (produces the sequence of the $409 \mathrm{bp}$ ) characteristic for this cultivar (Table 1) and some allele of group II (for example, Gli-B1q, present in genotypes of some Canadian cultivars). It was thereby implied that this genotype produced PCR sequences from both homologous chromosomes. Heterozygous seeds originating from undetected cross-pollination may occur in wheat grain samples of different origin and are considered as foreign seeds or admixtures [21].

\section{Discussion}

All the expressed genes located at a particular Gli locus are known to inherit virtually as a Mendelian unit, almost without recombination [6]. The rate of recombination between two of the most remote gliadin-coding genes harboured in a Gli-1 locus does not exceed 1\% [22]. These data imply tight clustering of the expressed gliadin genes at this locus.

However, analysis of large DNA sequences of the Gli loci showed that the distance of $10 \mathrm{~Kb}$ between two gliadin genes, around ten times more than the length of a gliadin gene $[4,13]$ itself, may be considered as unusually short and that the genes can be considered to be clustered [23]. In addition to noncoding gliadin sequences (pseudogenes, gene fragments) [14], transposable elements occupy most of the noncoding DNA between seed storage protein genes and occur in abundance at the distal end of the short arm of chromosome 1B [12,23-25].

The reason for the ability of several expressed gliadin genes, in spite of being relatively remote within the Gli locus, to be transmitted through intervarietal crosses as a unit with little visible signs of recombination, remains unclear. In order to understand the organization and function of the entire Gli locus, study and use of the polymorphism of its noncoding DNA sequences is required.

Two pairs of primers, GliB1.1 and GliB1.2, were developed for the analysis of the $\gamma$-gliadin pseudogene located within the Gli-B1 locus [16]. Nineteen known allelic variants of the Gli-B1 locus (revealed using APAGE of gliadin) were tested in our work using these pairs of primers, and a strict correspondence was discovered between variants of the EM of the $\gamma$-gliadin encoded by different alleles at the Gli-B1 locus and variants of the length of the PCR-produced sequence of the $\gamma$-gliadin pseudogene tested. At least seven principal variants of the Gli-B1 locus were distinguished. These variants are represented by four single alleles, Gli-B1a, Gli-B1b, Gli-B1d, Gli-B1h, and three allelic groups I, II, and III (without Gli-B1b). The seven variants differed in both their coding sequences (firstly, the EM 
of the major $\gamma$-gliadin, and, secondly, the composition of the entire block) and noncoding sequences (the length of the PCR-produced $\gamma$-gliadin pseudogene sequence).

The difference between variants at the distal end of chromosome 1B marked by different Gli-B1 alleles may be reinforced by two more genetic loci situated distally from, but closely linked to [26], Gli-B1, namely, Gli-B5 (where allele Gli-B5b encodes two faint $\omega$-gliadins) and $R g$-1, responsible for red glume colour. Analysis of a collection of common wheat varieties showed that the presence, in a certain wheat genotype, of any allele of groups I and II was nearly always accompanied by alleles Gli-B5b (Figure 1 and Figure S1) and Rg-1, while other alleles at the Gli-B1 locus occurred in genotypes together with the alleles Gli-B5a (the absence of the two faint bands) and $r g-1$ (white glume colour) [27]. This pattern was confirmed in Italian [28] and Spanish [29] wheat cultivars, although in each germplasm collection studied, single recombinant genotypes might occur. Hence, alleles of groups I and II, and the alleles Gli-B1c and Gli-B1h, occurred in wheat genotypes mainly with the allelic combination Gli-B5b $+R g-1$, while the presence of any other allele was accompanied by the combination Gli-B5a + rg-1. In the set of cultivars studied in the current work, the cultivar Krasnodonka (Figure 1k) had a recombinant genotype: the "red-colour allele" at Gli-B1 together with alleles Gli-B5a and $r g-1$.

The allele Gli-B1c (Figure 1j) produced the corresponding PCR sequence similar in length to that of the group III alleles at the Gli-B1 locus (Table 1). However, this allele marks a recombined variant of the distal part of the chromosome 1B: it encodes the set of gliadins (block), especially of the $\omega$-gliadins, different from that of the group III (Figure S1), and differs from other alleles of this group in being linked to the "red-colour" allelic combination, Gli-B5b + Rg-1. Therefore, the allele Gli-B1c may be considered as an eighth variant relatively independent from the group III alleles. In general, each homologous variant of chromosome $1 \mathrm{~B}$ in common wheat germplasm is marked by one of the eight distinct variants of the Gli-B1 locus.

Diploid donors of the genomes A, B and D might already have been polymorphic at the time of the origin of the tetraploid AABB and hexaploid AABBDD wheats, due to the differentiation of their genotypes at the diploid level [30]. We suggest that variants of the distal part of different homologous $1 \mathrm{~B}$ chromosomes marked by each one of eight different variants of the Gli-B1 locus were introduced into common wheat by considerably diverged genotypes of the donor(s) of the B genome. Due to the scarcity of recombination, each of the homologous variants of this chromosome's region may maintain intact (preserved from mixing) the precise gene (allelic) combination that came into common wheat from a particular genotype of the diploid donor. It is important to note that there are many agriculturally valuable genes in the distal part of the chromosome arms 1S [8,11].

The differences between homologous variants of common wheat chromosomes, especially of the B genome, were registered using cytological approaches [31,32]. It was assumed that these differences might cause a reduction in the number of chiasmata and chromosome pairing in intervarietal F1 hybrids compared to that of their parental inbred lines [31,33,34]. For the short arm of chromosome 1B (with the Gli-B1 locus in its distal region) this reduction, in some crosses, might reach $40 \%$ [35].

The degree of differences between homologous chromosomes may influence the recombination rate observed in intervarietal crosses. For example, the genetic distance between Gli-A3 and Gli-A1 loci varied among intervarietal crosses from $12.6 \%$ to $35.3 \%$ [36] or from $7 \mathrm{cM}$ to $27 \mathrm{cM}$ [37]. The distance between the Nor-B2 and Gli-B2 loci was about $2.0 \mathrm{cM}$ in a cross between the varieties Chinese Spring and Timstein, but $10.2 \mathrm{cM}$ for Chinese Spring crossed to the variety Cheyenne [38]. Hence, the differences between the DNA sequences in Chinese Spring and Timstein might be greater than those between Chinese Spring and Cheyenne. The recombination frequency between Gli-B1 and Rg-1 loci varied from $0.0 \%$ (two different crosses) to $2.7 \%$ and $4.8 \%$ in two further crosses [26]. In each of these four crosses, one parent was the cultivar Salmone (Gli-B1s), and the frequency of recombination in each case might have depended upon the variant of the Gli-B1 locus present in the second parent (alleles Gli-B1m, e, $b$, $b$, respectively). 
For chromosome $3 \mathrm{~B}, 82 \%$ of crossovers occurred in the distal region of chromosome $3 \mathrm{~B}$, representing only $19 \%$ of the chromosomal length [39]. Its "cold" areas (of low recombination rate) had a peculiar composition of transposable elements: a higher level of retrotransposons compared to DNA transposons [40]. The reduction in recombination rate in regions with a high density of retrotransposons could be due to DNA sequence variation created by their activity [41]. The negative impact of retroelements on recombination could also be attributed to their ability to condense DNA and lock the regions, preventing their accessibility to the recombination machinery [40]. The "cold" areas carry fewer and less expressed genes [40] and more single nucleotide substitutions (SNP) [10].

It is not clear if Gli-B1 is analogous to the case of a genetic locus situated inside the "cold" region of chromosome arm 3BS. Nevertheless, eight variants of alleles at the Gli-B1 locus may serve as markers of the distal part of homologous, but diverged, $1 \mathrm{~B}$ chromosomes.

The primary structure of the $\gamma$-gliadin polypeptides includes, besides other sequences, variable numbers of CAA-repeats and a small microsatellite encoding poly-glutamine [5]. The number of CAA-repeats in different $\gamma$-gliadin genes varied, in 170 wheat genotypes studied, from seven to 22 [13]. The visible differences in PCR sequence lengths produced by the $\gamma$-gliadin pseudogene GAG56B in several common wheat cultivars were caused by variation in the number of CAA-repeats in this sequence [15]. Our preliminary results showed that common wheat genotypes with alleles Gli-B1 $a$ and Gli-B1b produced, respectively, the longest (31 repeats) and the shortest (seven repeats) PCR sequence of GAG56B (L. Pascual, unpublished). There is no doubt that polymorphism in the length of the $\gamma$-gliadin pseudogene tested in our work with the GliB1.1 and GliB1.2 pairs of primers was mainly due to the number of CAA-repeats in its PCR sequence.

Microsatellite sequences might frequently change their length, with the mutation rate up to $2.4 \times 10^{-3}$ [42], or up to $5 \times 10^{-3}$ [43] per locus, per generation. In a series of microsatellite alleles, they differed from one another, as a rule, by two or three nucleotide pairs [44]. Hence, the difference in length of the microsatellite may cause the absence of exact identity between the PCR sequences produced by different cultivars having the same allele at the Gli-B1 locus (Gli-B1b, Gli-B1h or Gli-B1c) documented in our work.

The velocity of DNA divergence in noncoding regions was shown to be at least 3 to 4 times higher than in transcribed genes [45,46]. In the case of the Gli-B1 locus, however, the variation in the length of the $\gamma$-gliadin pseudogene PCR sequence correlated strictly with the polymorphism of the EM of the encoded $\gamma$-gliadin, which merits further study.

\section{Conclusions}

In this work, we compared nearly all allelic variants of the Gli-B1 locus revealed earlier in our study of gliadin genotypes in about 900 common wheat registered cultivars bred in 20th century. Analysis of allelic variation at the Gli-B1, Gli-B5, Rg-1 loci and at the $\gamma$-gliadin pseudogene located within the Gli-B1 locus permitted the identification of eight well-distinguished versions of the distal part of chromosome 1B in the germplasm studied. A correspondence was discovered between the length of the PCR sequences produced by different variants of the pseudogene, the variants present of the Gli-B1-controlled sets of gliadins (blocks), especially of the electrophoretic mobility of the encoded $\gamma$-gliadin, and the presence of the Gli-B5b $+R g-1$ allelic combination present in a certain wheat genotype. We suggest that distinct versions of the distal part of different homologous $1 \mathrm{~B}$ chromosomes (each of them marked by one of eight variants of the Gli-B1 locus), known to carry many agriculturally-important genes, were introduced into common wheat by diverged genotypes of the donor(s) of the B genome. Due to the scarcity of recombination, each of the homologous variants of this chromosome's region might maintain intact (preserving from mixing) the precise gene (allelic) combination that was incorporated into common wheat from a particular genotype of the diploid donor. Therefore, genetic polymorphism in this region of chromosome $1 \mathrm{~B}$ in registered cultivars bred in the 20th century might be essentially limited to these eight principal variants. 
As well as their evolutionary significance, these results are of potential use in wheat breeding in providing a simple means to select, via markers, for certain allelic combinations for this region across the generations of a genetic improvement programme. Furthermore, the results provide the knowledge base with which to compare the variation potentially present in hitherto unstudied collections of wheat germplasm, such as cultivars from other countries, landraces, and accessions of species related to common wheat, where we consider new and agronomically useful variants are likely to be found.

Supplementary Materials: The following is available online at http://www.mdpi.com/2073-4395/10/10/1510/s1, Figure S1: Scheme of sets of gliadin polypeptides (blocks) produced by allelic variants studied of the Gli-B1 locus. $\omega$-Gliadins encoded by the allele Gli-B5b are shown. B, the electrophoregram and scheme of its electrophoretic bands of the standard cultivar Bezostaya-1.

Author Contributions: Conceptualisation, E.M.; methodology, S.C., Y.P. and L.P.; software, V.M. and Y.P.; validation, W.J.R., L.P. and E.M.; investigation, Y.P., S.C. and E.M.; resources, M.R.-Q., S.C., L.P. and E.M.; writing-original draft preparation, E.M. and W.J.R. All authors have read and agreed to the published version of the manuscript.

Funding: This research received no external funding.

Conflicts of Interest: The authors declare no conflict of interest.

\section{References}

1. Payne, P.I. Genetics of wheat storage proteins and the effect of allelic variation on bread-making quality. Annu. Rev. Plant Physiol. 1987, 38, 141-153. [CrossRef]

2. Shewry, P.R.; Halford, N.G.; Lafiandra, D. Genetics of wheat gluten proteins. Adv. Genet. 2003, 49, 111-184. [PubMed]

3. Gobaa, S.; Bancel, E.; Branlard, G.; Kleijer, G.; Stamp, P. Proteomic analysis of wheat recombinant inbred lines: Variations in prolamin and dough rheology. J. Cereal Sci. 2008, 47, 610-619. [CrossRef]

4. Shewry, P.R.; Halford, N.G. Cereal seed storage proteins: Structures, properties and role in grain utilization. J. Exp. Bot. 2002, 53, 947-958. [CrossRef] [PubMed]

5. Barak, S.; Mudgil, D.; Khatkar, B.S. Biochemical and functional properties of wheat gliadins: A review. Crit. Rev. Food Sci. Nutr. 2015, 55, 357-368. [CrossRef]

6. Sozinov, A.A.; Poperelya, F.A. Genetic classification of prolamins and its use for plant breeding. Ann. Technol. Agric. 1980, 29, 229-245.

7. Metakovsky, E.; Melnik, V.A.; Rodriguez-Quijano, M.; Upelniek, V.P.; Carrillo, J.M. A catalog of glidin alleles: Polymorphism of 20th-century common wheat germplasm. Crop J. 2018, 6, 629-641. [CrossRef]

8. Sandhu, D.; Champoux, J.A.; Bondareva, N.; Gill, K.S. Identification and physical localization of useful genes and markers to a major gene-rich region on wheat group $1 \mathrm{~S}$ chromosomes. Genetics 2001, 157, 1735-1747.

9. Saintenac, C.; Faure, S.; Remay, A.; Choulet, F.; Ravel, C.; Paux, E.; Balfourier, F.; Feuillet, C.; Sourdille, P. Variation in crossover rates across a 3-Mb contig of bread wheat (Triticum aestivum) reveals the presence of a meiotic recombination hotspot. Chromosoma 2011, 120, 185-198. [CrossRef]

10. Jordan, K.W.; Wang, S.; He, F.; Chao, S.; Lun, Y.; Paux, E.; Sourdille, P.; Sherman, J.; Akhunova, A.; Blake, N.K.; et al. The genetic architecture of genome-wide recombination rate variation in allopolyploid wheat revealed by nested association mapping. Plant J. 2018, 95, 1039-1054. [CrossRef]

11. Gill, K.S.; Gill, B.S.; Endo, T.R.; Taylor, T. Identification and high-density mapping of gene-rich regions in chromosome group 1 of wheat. Genetics 1996, 144, 1883-1891. [PubMed]

12. Huang, X.Q.; Cloutier, S. Molecular characterization and genomic organization of low molecular weight glutenin subunit genes at the Glu-3 loci in hexaploid wheat (Triticum aestivum L.). Theor. Appl. Genet. 2008, 116, 953-966. [CrossRef] [PubMed]

13. Qi, P.F.; Wei, Y.M.; Ouellet, T.; Chen, Q.; Tan, X.; Zheng, Y.L. The $\gamma$-gliadin multigene family in common wheat (Triticum aestivum) and its closely related species. BMC Genom. 2009, 10, 168-181. [CrossRef] [PubMed]

14. van Herpen, T.W.J.M.; Goryunova, S.V.; van der Schoot, J.; Mitreva, M.; Salentijn, E.; Vorst, O.; Schenk, M.F.; van Veelen, P.A.; Koning, F; van Soest, L.J.M.; et al. Alpha-gliadin genes from the A, B, and D genomes of wheat contain different sets of celiac disease epitopes. BMC Genom. 2006, 7, 1. [CrossRef]

15. von Büren, M. Polymorphisms in two homoeologous gamma-gliadin genes and the evolution of cultivated wheat. Genet. Res. Crop Evol. 2001, 48, 205-220. [CrossRef] 
16. Zhang, W.; Gianibelli, M.C.; Ma, W.; Rampling, L.R.; Gale, K.R. Identification of SNPs and development of allele-specific PCR markers for gamma-gliadin alleles in Triticum Aestivum. Theor. Appl. Genet. 2003, 107, 130-138. [CrossRef]

17. Metakovsky, E.; Melnik, V.A.; Pascual, L.; Wrigley, C.W. Gliadin genotypes worldwide for spring wheats (Triticum aestivum L.). 2. Strong differentiation of polymorphism between countries and regions of origin. J. Cereal Sci. 2019, 87, 311-317. [CrossRef]

18. Doyle, J.J.; Doyle, J.L. Isolation of plant DNA from fresh tissue. Focus 1990, 12, 13-15.

19. Jackson, E.A.; Morel, M.H.; Sontag-Strohm, T.; Branlard, G.; Metakovsky, E.; Redaelli, R. Proposal for combining the classification systems of alleles of Gli-1 and Glu-3 loci in bread wheat (Triticum aestivum L.). J. Genet. Breed. 1996, 50, 321-336.

20. Cao, W.; Scoles, G.; Hucl, P.; Chibbar, R.N. The use of RAPD analysis to classify Triticum accessions. Theor. Appl. Genet. 1999, 98, 602-607. [CrossRef]

21. Metakovsky, E.; Melnik, V.A.; Pascual, L.; Romanov, G.A.; Wrigley, C.W. Types, frequences and value of intra-varietal genotypic non-uniformity in common wheat cultivars: Authentic biotypes and foreign seeds. J. Cereal Sci. 2019, 89. [CrossRef]

22. Metakovsky, E.; Branlard, G.; Chernakov, V.M.; Upelniek, V.P.; Redaelli, R.; Pogna, N.E. Recombiation mapping of some chromosome 1A-, 1B-, 1D- and 6B-controlled gliadins and low molecular weight glutenin subunits in common wheat. Theor. Appl. Genet. 1997, 94, 788-795. [CrossRef]

23. Gao, S.; Gu, Y.Q.; Wu, J.; Coleman-Derr, D.; Huo, N.; Crossman, C.; Jia, J.; Zuo, Q.; Ren, Z.; Anderson, O.D.; et al. Rapid evolution and complex structural organization in genomic regions harboring multiple prolamin genes in the polyploid wheat genome. Plant Mol. Biol. 2007, 65, 189-203. [CrossRef] [PubMed]

24. Charles, M.; Belcram, H.; Just, J.; Huneau, C.; Violett, A.; Couloux, A.; Segurens, B.; Carter, M.; Huteau, V.; Coriton, O.; et al. Dynamics and differential proliferation of transposable elements during the evolution of the B and A genomes of wheat. Genetics 2008, 180, 1071-1086. [CrossRef]

25. Wicker, T.; Mayer, K.F.X.; Gundlach, H.; Martis, M.; Steuernagel, B.; Scholz, U.; Šimková, H.; Kubaláková, M.; Choulet, F.; Taudien, S.; et al. Frequent gene movement and pseudogene evolution is common to the large and complex genomes of wheat, barley, and their relatives. Plant Cell 2011, 23, 1706-1718. [CrossRef]

26. Pogna, N.E.; Metakovsky, E.; Redaelli, R.; Raineri, F.; Dachkevitch, T. Recombination mapping of Gli-5, a new gliadin-coding locus on chromosome 1A and 1B in common wheat. Theor. Appl. Genet. 1993, 87, 113-121. [CrossRef]

27. Koval, S.F.; Metakovsky, E.; Kudryavtsev, A.M.; Sozinov, A.A. Non-accidental combinations of alleles at the $\mathrm{Hg}-1$ and $\mathrm{Rg}-1$ loci with definite alleles at the Gli-A1 and Gli-B1 loci in wheat. Selskokhoz. Biologia 1986, 2, 31-36.

28. Metakovsky, E.; Pogna, N.E.; Biancardi, A.M.; Redaelli, R. Gliadin allele composition of common wheat cultivars grown in Italy. J. Genet. Breed. 1994, 48, 55-66.

29. Metakovsky, E.; Gòmez, M.; Vàzquez, J.F.; Carrillo, J.M. High genetic diversity of Spanish common wheats as judged from gliadin alleles. Plant Breed. 2000, 119, 37-42. [CrossRef]

30. Dvorak, J.; Luo, M.C.; Akhunov, E.D. NI Vavilov theory of centres of diversity in the light of current understanding of wheat diversity, domestication and evolution. Czech J. Genet. Plant Breed. 2011, 47, S20-S27. [CrossRef]

31. Endo, T.R.; Gill, B.S. Somatic karyotype, heterochromatin distribution, and nature of chromosome differentiation in common wheat, Triticum aestivum L. em Thell. Chromosome 1984, 89, 361-369. [CrossRef]

32. Friebe, B.; Gill, B.S. C-band polymorphism and structural rearrangements detected in common wheat (Triticum aestivum). Euphytica 1994, 78, 1-5.

33. Dvořák, J.; Chen, K.C. Distribution of nonstructural variation between wheat cultivars along chromosome arm 6Bp: Evidence from the linkage map and physical map of the arm. Genetics 1984, 106, 325-333.

34. Dubcovsky, J.; Luo, M.-C.; Dvořák, J. Differentiation between homoeologous chromosomes 1A of wheat and 1Am of Triticum monococcum and its recognition by the wheat Ph1 locus. Proc. Nat. Acad. Sci. USA 1995, 92, 6645-6649. [CrossRef] [PubMed]

35. Dvořák, J.; McGuire, P.E. Nonstructural chromosome differentiation among wheat cultivars, with special reference to differentiation of chromosomes in related species. Genetics 1981, 97, 391-414. [PubMed] 
36. Metakovsky, E.; Chernakov, V.M.; Upelniek, V.P.; Redaelli, R.; Dardavet, M.; Branlard, G.; Pogna, N.E. Minor $\omega$-gliadin-coding loci on chromosome 1A of common wheat: A revision. J. Genet. Breed. 1996, 50, 277-286.

37. Dubcovsky, J.; Echaide, M.; Giancola, S.; Rousset, M.; Luo, M.-C.; Joppa, L.R.; Dvořák, J. Seed-storage-protein loci in RFLP maps of diploid, tetraploid and hexaploid wheat. Theor. Appl. Genet. 1997, 95, 1169-1180. [CrossRef]

38. Dvořák, J.; Appels, R. Investigation of homologous crossing over and sister chromatid exchange in the wheat Nor-B2 locus coding for rRNA and Gli-B2 locus coding for gliadins. Genetics 1986, 113, 1037-1056.

39. Choulet, F.; Alberti, A.; Theil, S.; Glover, N.; Barbe, V.; Daron, J.; Pingault, L.; Sourdille, P.; Couloux, A.; Paux, E.; et al. Structural and functional partitioning of bread wheat chromosome 3B. Science 2014, 345, 1249721. [CrossRef]

40. Darrier, B.; Rimbert, H.; Balfourier, F.; Pingault, L.; Josselin, A.A.; Servin, B.; Navarro, J.; Choulet, F.; Paux, E.; Sourdille, P. High-resolution mapping of crossover events in the hexaploid wheat genome suggest a universal recombination mechanism. Genetics 2017, 206, 1373-1388. [CrossRef]

41. Dvořák, J.; Yang, Z.L.; You, F.M.; Luo, M.C. Deletion polymorphism in wheat chromosome regions with contrasting recombination rates. Genetics 2004, 168, 1665-1675. [CrossRef] [PubMed]

42. Thuillet, A.-C.; Bru, D.; David, J.; Roumet, P.; Santoni, S.; Sourdille, P.; Bataillon, T. Direct estimation of mutation rate for 10 microsatellite loci in durum wheat, Triticum turgidum (L.) Thell. ssp durum desf. Mol. Biol. Evol. 2002, 19, 122-125. [CrossRef] [PubMed]

43. Raquin, A.-L.; Depaulis, F.; Lambert, A.; Galic, N.; Brabant, P.; Goldringer, I. Experimental estimation of mutation rates in a wheat population with a gene genealogy approach. Genetics 2008, 179, 2195-2211. [CrossRef] [PubMed]

44. Huang, X.Q.; Börner, A.; Röder, M.S.; Ganal, M.W. Assessing genetic diversity of wheat (Triticum aestivum L.) germplasm using microsatellite markers. Theor. Appl. Genet. 2002, 105, 699-707. [CrossRef]

45. Wicker, T.; Stein, N.; Albar, L.; Feuillet, C.; Schlagenhauf, E.; Keller, B. Analysis of a contiguous 211 Kb sequence in diploid wheat (Triticum monococcum) reveals multiple mechanisms of genome evolution. Plant J. 2001, 26, 307-316. [CrossRef]

46. Isidore, E.; Scherrer, B.; Chalhoub, B.; Feuillet, C.; Keller, B. Ancient haplotypes resulting from extensive molecular rearrangements in the wheat A genome have been maintained in species of three different ploidy levels. Genome Res. 2005, 15, 526-536. [CrossRef] 